\title{
Groundwater study of Manoharthana Block of Jhalawar District in State of Rajasthan,India.
}

\author{
S.K.Maanju* \\ *S.S.in Earth Science, Vikram University, Ujjain(M.P.)
}

\begin{abstract}
Water is found covering one-third part of the earth in various forms. In India total quantity of water is $1900,000 \times 10^{16} \mathrm{~m}^{3}$. Rajasthan has paucity of water resource due to low and erratic rainfall. In Jhalawar district, Manoharthana block is one of the areas which have been facing the problem of less availability of potable water quantity-wise and quality-wise higher nitrate concentration at few locations is noticed.However, it is not posing serious health hazards in this area. The ground water is only main source of fresh water supply.

Key words: Groundwater, hydrogeology and hydrochemistry, etc.
\end{abstract}

\section{Introduction}

\section{Introduction}

Water is one of the most essential substances for sustenance of life on earth i.e. without which life is not possible. The sum total of all the water on the earth constitutes hydrosphere. The aqueous envelop of the earth comprising of the oceans, lakes, streams, underground water, polar and mountain glaciers, soil moisture and the vapors present in the atmosphere are part of hydrological cycle. These natural water resources are moving in cyclic manner.

\section{Physiography And Drainage}

The area of investigation is located in Manoharthana block of Jhalawar district in Rajasthan State. On the south-west and east, it touches the border of Madhya Pradesh. The area of study lie within latitude $24^{\circ} 07^{\prime}$ to $24^{\circ} 30^{\prime} \mathrm{N}$ and longitude $76^{\circ} 23^{\prime}$ to $76^{\circ} 58^{\prime} \mathrm{E}$ falling on survey of India Toposheet number 54/D and covering an area of about $937.46 \mathrm{sq} . \mathrm{km}$.

Physiographically, the study area- Manohar Thana of Jhalawar district is divided in two main parts, southern part is marked by the Malwa plateau while northern part is characterized by the Mukandra mountain series. The part of the area and some hilly parts are covered by lateritic soils. The leteritic soil is marked by the excess of alumina.

The area is drained by the Chhapi River, Parwan River and Parvati River and all these Rivers are seasonal. The area has semi-arid climate and rainfall occurs by south-west monsoon system. The winter season runs from mid of December to February and summer from April to June. The period from mid of June to September is the monsoon season followed by the months- October to mid of November which constitutes the post monsoon or the retreating monsoon. The rainfall mostly occurs as storm bursts and is erratic and caused by south western monsoon system. The average rainfall from period of 2001-2010 is $751.17 \mathrm{~mm} /$ year. Precipitation mainly occurs in the months of June, July, August and September except few showers in winter season.

\section{Geological Set-Up}

The geology of the present study area is mainly represented by the Vindhyan super group and basaltic flow of Deccan trap. The volcanic activity had occurred during upper Cretaceous to Paleocene period.

The Jhalawar area forms the south western marginal part of the Vindhyans of Rajasthan. In this area, an alternate sequence of shale's, limestone's and sandstones of the Lower and Upper Vindhyan super group forms a major anticline structure known as the Jhalawar Anticline with its trend in NW-SE direction.

\section{Local Geology}

Local geological formation of the study area is as follows:

\begin{tabular}{|c|c|c|c|c|}
\hline Super Group & Group & Formation & Lithology & Age \\
\hline & & & Alluvium soil & Recent \\
\hline & & & $\begin{array}{c}\text { Lateritic soil and black } \\
\text { cotton soils }\end{array}$ & Pleistocene \\
\hline Deccan trap & & Middle trap & Blow 2 flows and red \\
& Fole & Cretaceous to Eocene \\
& Flow 1 & Base not exposed \\
\hline
\end{tabular}


The local geology of the area is characterized by the middle Deccan traps of basaltic lava flows. In Manohartana area, two types of basaltic lava flows have been observed on the basis of petrographic study and the description of these flows is given below:

First Flow: - In this flows rock is totally vesicular in nature. It is brown to pale brownish in color. The rock of first flow is characterized by the incidence of fractures and joints. This flow is separated from second lava flow by red bole layer.

Second Flow: - The second flow rock is characterized by presence of big boulders on its crown. The boulders are vesicular and jointed in nature. This flow has potential water bearing zones as it is very much weathered and jointed.

\section{Hydrogeology}

The ground water potential in hard rock's depends upon the joints and fracture system present in such rocks. The secondary porosity is also developed by weathering and fracturing. The viability, occurrence and movement of ground water depend upon the topography, structure, geomorphology and the hydraulic properties of water bearing materials. In the present study area, weathered basalts and sandstone are main water bearing formations.

The well inventory information such as the location of dug well, diameter, total depth of water level and discharge etc. in the wells were measured in seventeen selected key wells of the study area which is summarized below in tabular form.

\begin{tabular}{|c|c|c|c|c|c|c|}
\hline S.NO & VILLAGE/TOWN & $\begin{array}{l}\text { RL(ABOVE } \\
\text { MSL) }\end{array}$ & $\begin{array}{l}\text { WELL } \\
\text { DIAMENTION }\end{array}$ & $\begin{array}{l}\text { TOTAL } \\
\text { DEPTH }\end{array}$ & $\begin{array}{l}\text { WATER } \\
\text { LEVEL(BGL) }\end{array}$ & $\begin{array}{l}\text { DISCHARGE } \\
\text { OF } \\
\left.\text { WELL(M }{ }^{3} / \text { DAY }\right)\end{array}$ \\
\hline 1 & Aklera & 322 & 5.50 & 10.0 & 7.79 & 5 \\
\hline 2 & Ametha & 328 & 6.95 & 7.55 & 4.93 & 35 \\
\hline 3 & Anwelhera & 346 & 6.10 & 9.20 & 4.71 & 40 \\
\hline 4 & Chhan & 325 & 3.50 & 10.90 & 6.22 & 45 \\
\hline 5 & Chhitaura & 360 & 2.90 & 17.50 & 15.53 & 40 \\
\hline 6 & Churaliya & 340 & & 11.0 & 6.20 & 40 \\
\hline 7 & Dangipura & 370 & 6.60 & 11.60 & 11.09 & 25 \\
\hline 8 & Deorideo & 407 & 6.70 & 8.75 & 3.27 & 30 \\
\hline 9 & Ganeshpura barod & 322 & 4.30 & 9.95 & 5.60 & 35 \\
\hline 10 & Jhiri & 360 & 5.20 & 6.60 & 3.78 & 40 \\
\hline 11 & Khatakheri & 340 & 4.00 & 10.80 & 7.15 & 25 \\
\hline 12 & Lahas & 320 & 6.1 & 9.20 & 6.70 & 35 \\
\hline 13 & Maharajapura & 400 & 5.40 & 7.90 & 4.44 & 25 \\
\hline 14 & Manoharthana & 340 & 4.30 & 17.05 & 14.30 & 10 \\
\hline 15 & Samrol & 340 & 2.90 & 8.35 & 3.32 & 30 \\
\hline 16 & Sareri & 320 & 6.60 & 15.60 & 12.74 & 50 \\
\hline 17 & Thaural & 315 & 4.60 & 8.80 & 4.11 & 35 \\
\hline
\end{tabular}

\section{Groundwater Quality}

Water in its chemically pure form occurs rarely in nature. In fact water is commonly containing variety of constituents. When water in its precipitate form reaches the surface of the earth, it has already captured a number of substances. Gases have also been incorporated as well as dissolved dust particles are picked up.

Atmospheric water changes its quality both upon reaching the earth's surface and during its percolation to underground water body. The dissolved salts are in part are retained in the topsoil where carbon dioxide is also released by bacterial action on organic matter. The soil water becomes charged with carbon dioxide resulting in formation of carbonic acid.

Man's influence on deterioration of quality of water is quite apparent and is now a major concern. Mixing of municipal and industrial waste, water may result in drastic changes in the quality of natural waters. Agriculturally related activities such as use of fertilizer, pesticides, herbicides, etc., may lead to pollution of both surface waters and ground water. Irrigation return water also tends to increase total salts in the groundwater. Mining activities often bring substantial water quality changes. The main constituents of ground water are major cations $\left(\mathrm{Ca}^{+}, \mathrm{Mg}^{+}, \mathrm{Na}^{+}, \mathrm{K}^{+}\right)$and major anions $\left(\mathrm{Cl}^{-}, \mathrm{SO}_{4}{ }^{--}, \mathrm{HCO}_{3}{ }^{-}, \mathrm{CO}_{3}{ }^{--}, \mathrm{NO}_{3}{ }^{--}\right)$which were analyzed and tabulated below strictly according to serial number as given in above table viz. serial number 1 means key well of Aklera and so on and so forh. 
Groundwater study of Manoharthana Block of Jhalawar District in State of Rajasthan,India.

Chemical Analysis Of Selected Seventeen Ground Water Samples In Ppm

\begin{tabular}{|c|c|c|c|c|c|c|c|c|c|c|c|c|c|c|c|c|}
\hline S.No & pH & TDS & EC & $\mathrm{Na}^{+}$ & $\mathbf{K}^{+}$ & $\mathrm{Ca}^{+}$ & $\mathrm{Mg}^{+}$ & $\mathrm{Cl}^{-}$ & $\mathrm{SO}_{4}^{--}$ & $\mathrm{CO}_{3}^{--}$ & $\mathrm{HCO}_{3}^{--}$ & $\mathrm{NO}_{3}^{-}$ & $\mathbf{F}$ & TH & $\mathrm{Na} \%$ & SAR \\
\hline 1 & 7.8 & 464 & 700 & 65 & 2 & 56 & 30 & 14 & 72 & - & 366 & 42 & 0.64 & 265 & 34.60 & 1.74 \\
\hline 2 & 7.6 & 439 & 920 & 50 & 4 & 36 & 60 & 71 & 5 & - & 378 & 25 & 0.48 & 335 & 24.19 & 1.19 \\
\hline 3 & 7.9 & 455 & 920 & 78 & 3 & 78 & 12 & 71 & 5 & - & 330 & 43 & 0.40 & 245 & 40.50 & 2.17 \\
\hline 4 & 8.0 & 500 & 950 & 70 & 15 & 78 & 22 & 64 & 67 & - & 293 & 38 & 0.30 & 285 & 33.33 & 1.85 \\
\hline 5 & 7.7 & 450 & 800 & 18 & 22 & 26 & 74 & 99 & 58 & - & 268 & 19 & 0.30 & 370 & 8.92 & 0.41 \\
\hline 6 & 8.0 & 516 & 890 & 68 & 22 & 60 & 24 & 71 & 67 & - & 317 & 45 & 0.80 & 250 & 34.74 & 1.87 \\
\hline 7 & 7.9 & 416 & 870 & 62 & 29 & 56 & 5 & 35 & 43 & - & 256 & 58 & 0.30 & 160 & 40.66 & 2.13 \\
\hline 8 & 7.8 & 513 & 800 & 64 & 22 & 60 & 24 & 57 & 130 & - & 256 & 49 & 0.30 & 265 & 20.97 & 1.28 \\
\hline 9 & 7.9 & 384 & 810 & 40 & 18 & 36 & 51 & 92 & 10 & - & 244 & 15 & 0.10 & 300 & 21.22 & 1.00 \\
\hline 10 & 7.6 & 344 & 540 & 70 & 7 & 48 & 7 & 14 & 5 & - & 330 & 28 & 0.30 & 150 & 48.87 & 2.48 \\
\hline 11 & 7.8 & 549 & 990 & 115 & 0 & 60 & 15 & 43 & 149 & - & 281 & 28 & 0.80 & 210 & 58.35 & 3.45 \\
\hline 12 & 8.0 & 503 & 930 & 44 & 0 & 40 & 73 & 71 & 1 & - & 488 & 30 & 1.48 & 400 & 19.27 & 0.96 \\
\hline 13 & 7.4 & 343 & 550 & 45 & 1 & 40 & 24 & 57 & 5 & - & 195 & 74 & 0.88 & 200 & 32.78 & 1.39 \\
\hline 14 & 7.8 & 468 & 800 & 70 & 4 & 60 & 24 & 43 & 101 & - & 244 & 44 & 1.32 & 250 & 37.35 & 1.92 \\
\hline 15 & 7.5 & 572 & 930 & 70 & 5 & 80 & 46 & 142 & 2 & - & 342 & 55 & 0.58 & 390 & 27.71 & 1.54 \\
\hline 16 & 7.8 & 532 & 860 & 50 & 5 & 100 & 33 & 64 & 120 & - & 281 & 20 & 0.88 & 385 & 21.70 & 1.11 \\
\hline 17 & 8.1 & 455 & 800 & 70 & 21 & 42 & 45 & 71 & 14 & - & 354 & 15 & 0.60 & 290 & 32.41 & 1.79 \\
\hline
\end{tabular}

\section{Conclusion}

It is observed that this research work provide significant information about the nature of ground water which is potable largely except higher concentration of nitrate at two -three locations in Manoharthana block of Jhalawar district. A vast data have been generated which are useful for development of a model for exploration and management of groundwater resource in Manoharthana block of Jhalawar district in state of Rajasthan.

It is observed that the present investigation is also useful for water supply department as well as for local residents. Apart from this, the data can be used for further advance research in the area by agencies engaged in groundwater studies.

\section{References}

[1]. Karanth, K.R., 1989. Hydrogeology. Tata Mc Graw Hill Publishing Company Limited Asaf Ali Road, New Delh, 458 p.

[2]. Krishnan, M.S., 1982. Geology of India and Burma. CBS Publication by CBS publishers and Distributors.

[3]. Raghunath, H.M. 1987. Hydrogeology. Wiley Eastern Limited, New Delhi, 482p.

[4]. Singh, P. 1969. Engineering and General Geology. S.K. Kataria \& Sons, Ansari Road Daryaganj, New Delhi, 431p.

[5]. Todd, D.K. 1959. Ground Water Hydrology. John Wiley \& Sons, New York, 535p.

[6]. Tomer Chaterbuhj (1991) Hydrogeological survey of basaltic terrain of Tilawad, Shajapur District M.P.

[7]. Williams, Howel and Francis, J. Turner and Charles, M, Gilbeert, 1985. Petrography. C.B.S. Publishers \& Distributors, 485p.

[8]. Unpublished M.Phil Thesis of Kaushik Dudwe, Vikram University,Ujjain 